\title{
Performance and genetic assessment of rubber tree clones in Southern Thailand
}

\author{
Denduang Pethin, Korakot Nakkanong, Charassri Nualsri*
}

Prince of Songkla University/Faculty of Natural Resources - Dept. of Plant Science - 90112 - Hat Yai - Songkhla Thailand.

*Corresponding author <ncharass@yahoo.com>

Edited by: Cláudio Marcelo Gonçalves de Oliveira

Received June 09, 2014

Accepted March 09, 2015

\begin{abstract}
Thailand is the world leader in the production of latex extracted from the rubber tree (Hevea brasiliensis). However, the most cultivated clone RRIM 600, is highly susceptible to diseases, and there is economic incentive to develop new rubber tree clones. Four rubber tree clones (T2, SK1, NK1 and SK3) that have high latex yield potential from plantations in Southern Thailand were selected for this study. Yield performance, latex biochemical parameters and anatomical characteristics of bark were monitored for two years, using RRIM 600 clones in the same fields as paired controls. The average yields of the clones SK1, NK1 and SK3 were 129.3, 74.2 and $53.9 \mathrm{~g}$ per tree per tapping, respectively, surpassing the paired RRIM 600 controls $(94.3,49.9$ and 43.9 $\mathrm{g}$ per tree per tapping in matching order). There was a difference in girth increment of SK1, SK3 and T2 clones when compared with RRIM 600, whereas the clones SK1 and T2 had higher renewed bark thickness than the paired RRIM 600. The anatomical measurements showed that the diameter of the latex vessels and density of latex vessels $\mathrm{mm}^{-2}$ were the highest in clone NK1, which also had the best latex biochemical parameters. This indicates NK1 is superior, and supports its use in Hevea breeding programs to improve latex yield. Our genetic characterization and assessment of the four clones selected used Random Amplified Polymorphic DNA (RAPD) and Simple Sequence Repeats (SSR). Seventeen recommended rubber clones were included as references. The clones SK3 and SK1 were closely related to RRIM 600 with similarity coefficients of 0.891 and 0.809 , while NK1 and T2 were closely related to RRIT 250 (0.836) and RRIC 110 (0.864), respectively. Keywords: Hevea brasiliensis, Random Amplified Polymorphic DNA, latex yield, latex biochemical parameters, anatomical characteristics of bark
\end{abstract}

\section{Introduction}

Rubber tree (Hevea brasiliensis Muell.-Arg.) is among the most important economic crops in the world. Latex is the major product from this species while rubber wood (lumber) is considered a secondary product (Priyadarshan et al., 2009). Thailand is the world leader in natural rubber production, and most of the production areas (1.76 million ha) are in the southern part of the country. The clone RRIM 600 is grown in $75 \%$ of the rubber production area in Thailand, and has been in use for more than 60 years. However, RRIM 600 is highly susceptible to diseases caused by the Phytophthora species (Thanseem et al., 2005). Therefore, there is economic incentive to develop new rubber tree clones.

Rubber tree breeding programs have traditionally relied on generating crosses and progeny lines and screening them for further selective breeding. One testing cycle takes about 20 to 30 years. These programs, focusing on production, can be speeded up and made more effective by the use of both agronomic performance and the anatomical characteristics of bark and biochemical parameters as selection criteria /Gonçalves et al., 2005a). The anatomical characteristics of bark are related to the latex yield of a rubber tree (Webster and Paardekooper, 1989).

Observations of the laticiferous system characteristics, such as latex vessel diameter and density of latex vessels, can assist in the selection of high yielding clones (Mesquita et al., 2006). Moreover, the biochemical parameters of latex itself also relate to the latex yield predictively (Bricard and Nicolas, 1989). Genetic variability information of the parental clones is required for parental selection in Hevea breeding, since the crossing of genetically distant clones increases the possibility of heterosis (Oktavia and Kuswanhadi, 2011).

The genetic distance of clones cannot be assessed from their morphological characteristics. Instead molecular markers such as Random Amplified Polymorphic DNA (RAPD) and Simple Sequence Repeats (SSR) have been used to estimate such genetic distances (Venkatachalam et al., 2007). This study mainly aimed to investigate latex production, latex biochemical parameters, and anatomical characteristics of high of the bark of latex yielding open pollinated clones, using RRIM600 clones as a baseline for comparisons. The genetic distances of these rubber clones along with various recommended clones were assessed based on RAPD and SSR markers.

\section{Materials and Methods}

\section{Plant materials}

The four clones selected that had high latex yield were sampled from rubber plantations in three provinces in southern Thailand. Each clone is herein designated with a label stemming from the sampling location. The private farm locations were in Songkhla province (1004 $41^{\prime} 37.1^{\prime \prime} \mathrm{N}, 6^{\circ} 46^{\prime} 27.2^{\prime \prime} \mathrm{E}-\mathrm{SK} 1$ and $100^{\circ} 20^{\prime} 35.8^{\prime \prime}$ N, 6059'290" E - SK3), Nakhon Si Thammarat province (99²9'32.6" N, 859.9'290" E - NK1) and Trang province $\left(99^{\circ} 53^{\prime} 2.11^{\prime \prime} \mathrm{N}, 7^{\circ} 16^{\prime} 50.36^{\prime \prime} \mathrm{E}-\mathrm{T} 2\right)$. Based on the 
information provided by those managing each plantation, the 13-year-old sampled trees originating from the seedlings of open pollinated progenies.

The experimental design was a randomized complete block with three replications. In each location, 15 plants representing the selected rubber tree clone and also RRIM 600 were chosen for sampling. The selection of trees from each rubber plantation was made on the basis of their daily yield patterns and on fairly uniform circumferences of $100-150 \mathrm{~cm}$. The tapping system for all the sampled trees was a one-third spiral downward cut, with a cycle of two days with tapping and one day of rest (1/3S $2 \mathrm{~d} / 3)$. No stimulants were employed to enhance the latex yield.

The latex collected from each tree was monitored, and the cumulative dry rubber production was recorded twice a month. To determine the dry rubber content (DRC) in latex, it was weighed prior to coagulation in the cup in a $6 \%$ acetic acid solution, mixed well, and after 10-20 min coagulated latex was obtained. The coagulated solid rubber was separated from the liquid serum, made into a thin sheet, air dried in a hot oven at $65^{\circ} \mathrm{C}$ for $24 \mathrm{~h}$, and the dry rubber mass in the latex was weighed. For growth analysis, the trunk girth increment and the renewed bark thickness were measured once a month at the tapping height, which was approximately 1.50-1.80 $\mathrm{m}$ above ground.

\section{Measurement of biochemical parameters}

We assessed the high yielding rubber clones by the biochemical composition of their latex, which relates to the physiological characteristics of latex synthesis. The latex diagnosis was carried out monthly during the course of the experiments (2011-2013). The biochemical parameters evaluated were total solid content (TSC), sucrose (Suc), inorganic phosphorus (Pi), and thiol contents (RSH). The latex samples were collected as follows: a tine was stabbed approximately to a depth of $5 \mathrm{~cm}$ into the trunk of a rubber tree, at a 30-degree angle, about 5 $\mathrm{cm}$ under the tapping cut, and a plastic tube was inserted into the opening to transport latex. At each sampling the first few drops of latex were discarded, and a sample from each tree was collected in one and the same glass tube for approximately a $2 \mathrm{~mL}$ total, representing one clone in one field. Once this latex sample was collected, the rubber in it was precipitated immediately by a mixture of TCA (trichloroacetic acid) and EDTA (Ethylenediaminetetraacetic acid), separated out, and the remaining liquid was transferred into a storage box held at $4{ }^{\circ} \mathrm{C}$. The parameters TSC, Suc, Pi and RSH were measured from these clear serum liquid samples, known as TCAserum (Eschbach et al., 1984). The sucrose, Pi and RSH contents are expressed here in millimols.

\section{Bark anatomical evaluation}

Five-month-old buddings of rubber trees (SK1, SK3, NK1, T2, RRIM 600 and RRIT 251) were grown in a field in the Songkhla province, Thailand $\left(07^{\circ} 0^{\prime} 28.8^{\prime \prime}\right.$
$\left.\mathrm{N} ; 100^{\circ} 30^{\prime} 0^{\prime \prime} \mathrm{E}\right)$. This experiment was conducted in the period from May $5^{\text {th }}$ to June $30^{\text {th }}$ in 2013. The rubber trees were approximately 2-3 m tall, and their canopy widths approximately $1.5-2.5 \mathrm{~m}$ during this period. The bark was cut perpendicularly to the stem at the ground level (at approximately $0.5 \mathrm{~cm}$ height). The bark samples were fixed in a mixture of FPA (formalin: Pioneer Romano Prodi acid: $70 \%$ alcohol, mixed in a volumetric ratio of $5 \mathrm{~mL}$ : $5 \mathrm{~mL}$ : $90 \mathrm{~mL}$ ) for $24-48 \mathrm{~h}$, subsequently dehydrated by soaking in an ethyl-butyl series. Samples were infiltrated and embedded in paraffin, and tissue samples were cut (approximately $5 \mu \mathrm{m}$ thick). These were stained with safranin, fast green and orange G. The stained sections were viewed and photographed on slides, using a compound light microscope.

\section{DNA extraction}

The sampled clones selected were genetically probed by RAPD and SSR markers for genomic similarity assessments. Seventeen clones, available at the beginning of this experiment, were included as representative materials. Some clones, such as RRIM 600, RRIT 251 and RRIT 250 were recommended clones, whereas others had been used as parents in various rubber tree breeding programs in Thailand. The DNA was extracted from approximately $200 \mathrm{mg}$ of young fresh leaves, in accordance with the procedure for extraction and purification as modified by Doyle and Doyle (1990). The amount of DNA was estimated by electrophoresis and a known amount of $\lambda$ DNA was used as the standard.

\section{RAPD protocol}

The 120 10-base oligonucleotide primers in the A, $B, C, R, T$ and $Z$ Kits were used in the first phase of screening. The amplification reaction was performed in a reaction volume of $25 \mu \mathrm{L}$, containing $2.5 \mu \mathrm{L}$ of $10 \mathrm{x}$ buffer, $3.0 \mu \mathrm{L}$ of $25 \mathrm{mM} \mathrm{MgCl}, 200 \mu \mathrm{M}$ of each dNTP, 0.3 $\mu \mathrm{M}$ of primer, $0.2 \mu \mathrm{L}$ (1.0 unit) of Taq DNA polymerase and $1.0 \mu \mathrm{L}(100 \mathrm{ng})$ template DNA. The amplifications were made in a thermocycler. The thermal profile for PCR (Polymerase Chain Reaction) was started from 35 cycles at $94{ }^{\circ} \mathrm{C}$ for $30 \mathrm{~s}, 37^{\circ} \mathrm{C}$ for $30 \mathrm{~s}, 72^{\circ} \mathrm{C}$ for $1 \mathrm{~min}$, and finally at $72{ }^{\circ} \mathrm{C}$ for $5 \mathrm{~min}$. After amplification, 10 $\mu \mathrm{L}$ of the PCR products were separated by electrophoresis at $50 \mathrm{~V}$ for 2 hours and $30 \mathrm{~min}$, on $2 \%$ agarose LE (Low Electroendosmosis) using TBE buffer (Tris-borate-

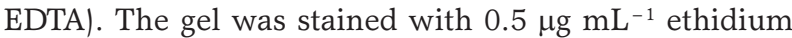
bromide for $30 \mathrm{~min}$, washed by soaking in double deionized water for $20 \mathrm{~min}$, and photographed using a gel documentation system.

\section{SSR protocol}

Initially, the four SSR primer pairs hmac4, hmac 5 , hmct1 and hmct 5, from prior research (Nakkanong et al., 2008; Saha et al., 2005), and another six primers from the Genbank database (AF383928, AF383930, AF383931, AF383932, AF383933 and AF383935) were used for PCR amplification of DNA, following the proto- 
col from Saha et al. (2005). The PCR reaction was carried out in $10 \mu \mathrm{L}$ final volume containing $20 \mathrm{ng}$ of genomic DNA, $2.5 \mathrm{mM} \mathrm{MgCl}_{2}$, 10x Taq buffer, $0.2 \mu \mathrm{M}$ each of the forward and reverse primers, $200 \mu \mathrm{M}$ dNTPs, and 0.7 units of Taq polymerase. The amplifications were made in a thermocycler. The temperature profile involved an initial denaturation step of $5 \mathrm{~min}$ at $95{ }^{\circ} \mathrm{C}$, followed by a touch-down PCR program. Temperature profile of the touch-down PCR for seven cycles was: $94^{\circ} \mathrm{C}$ for $30 \mathrm{~s}, 63$ ${ }^{\circ} \mathrm{C}$ for $1 \mathrm{~min}$, decreasing by $1{ }^{\circ} \mathrm{C}$ for each of the seven cycles, and finally $72{ }^{\circ} \mathrm{C}$ for $1 \mathrm{~min}$. This was followed by a normal cycling of $94{ }^{\circ} \mathrm{C}$ for $30 \mathrm{~s}, 56{ }^{\circ} \mathrm{C}$ for $1 \mathrm{~min}$, and $72{ }^{\circ} \mathrm{C}$ for $1 \mathrm{~min}$ for 23 cycles, and a final extension at $72{ }^{\circ} \mathrm{C}$ for $10 \mathrm{~min}$. The touch-down protocol was used to eliminate stuttering and artifact bands. The amplification products were run on a $6 \%$ denaturing polyacrylamide gel containing $7 \mathrm{M}$ urea using $0.5 \mathrm{TBE}$ buffer at $1,000 \mathrm{~V}$, and the DNA bands were visualized with silver nitrate.

\section{Data analysis}

The data on latex yield, girth increment, renewed bark thickness and biochemical parameters were analyzed using Student's t-test. Means of diameter and density of latex vessels were compared for significant differences using Duncan's Multiple Range Test (DMRT). RAPD and SSR reproducible fragments were scored for presence or absence of the band for RAPD, and for presence or absence of an allele in the locus for SSR. The bands were then entered in a computer file as a binary matrix, and analyzed by NTSYS pc-version 2.1. The hierarchical clustering algorithm UPGMA was used to construct dendrograms separately for the RAPD and the SSR markers, with slightly different results in the similarities of genotypes, showing that these sets of markers provide complementary information on genetic similarity. Therefore, the data from both markers were combined for maximal information (Ahmed et al., 2012; Zhan et al., 2012), and analyzed for seventeen recommended genotypes and the four rubber clones selected. The genetic distances were quantified by means of the Jaccard index, to arrive at the similarity matrix used in the clustering.

\section{Results and Discussion}

\section{Evaluation of latex yield and growth after tapping}

The clones studied presented varying levels of latex yield and growth performance after tapping. The latex yield was recorded fortnightly by coagulating the latex in a cup, drying and weighing the coagulum. The average dry rubber yield per tree per tapping of SK1 was highest at $129.3 \mathrm{~g}$ per tree per tapping followed by NK1 (74.2 g per tree per tapping), SK3 (53.9 g per tree per tapping) and T2 (42.2 g per tree per tapping). All the clones selected had higher latex yields than the paired RRIM 600 controls, paired to match the site, although there was no yield difference between T2 clone and RRIM 600
(Figure 1). For two years, the girth increments differed upwards from the paired controls (RRIM 600) for the high yield clones SK1, SK3 and T2 (Table 1), while the clone NK1 showed no difference to the control. The renewed bark thicknesses of T2 and SK1 clones were 8.91 and $7.72 \mathrm{~mm}$, respectively, and were higher than for RRIM 600. However, the SK3 and NK1 clones showed no such difference from RRIM 600 (Table 2).

This appears to be the first study to report details of yield from select high yield rubber tree clones on actual farms in Thailand. The economic importance of yield is a natural driver for clonal selection in selective breeding designed to improve the clones. The superior performance of SK1 over the RRIM 600, currently dominant on farms in Thailand, is noteworthy. The SK1 clone had higher yield and growth in terms of latex yield, girth increment and renewed bark thickness. Thick bark is a very important characteristic, because it minimizes the wounding incidences that are known to affect productivity after tapping (Gonçalves et al., 2007). Even the single

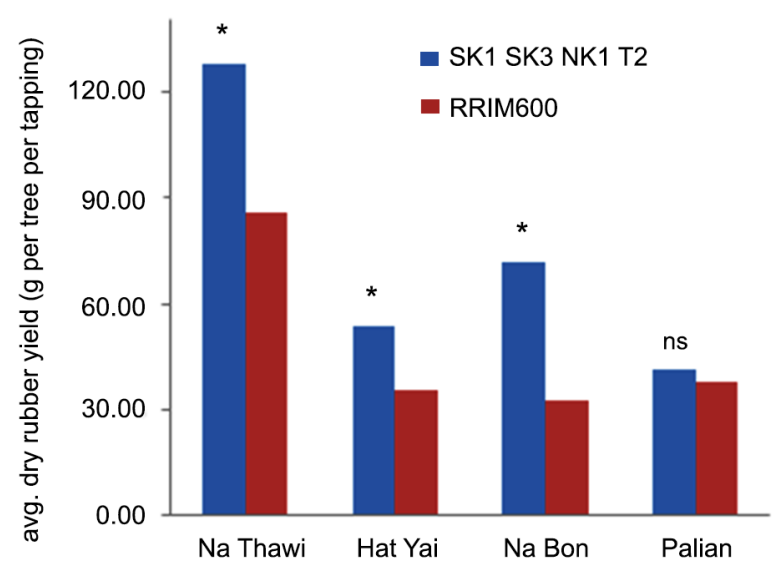

Figure 1- Average dry rubber yield (g per tree per tapping) of four selected rubber clones: Na Thawi (SK1), Hat Yai (SK3), Na Bon (NK1) and Palian (T2). In each site, RRIM 600 was used as a control during 2011-2013.

Table 1 - Girth increment of SK1, SK3, NK1 and T2 rubber tree clones compared with RRIM 600 grown in the same farmer trail. The data were recorded from 2011 to 2013.

\begin{tabular}{|c|c|c|c|}
\hline Clone & Girth increment & t-test & C.V. \\
\hline & $\mathrm{cm}$ & & $\%$ \\
\hline SK1 RRIM 600 & $\begin{array}{l}1.09 \pm 0.05 a \\
0.68 \pm 0.04 b\end{array}$ & * & 15 \\
\hline SK3 RRIM 600 & $\begin{array}{l}1.57 \pm 0.04 \mathrm{a} \\
0.41 \pm 0.11 \mathrm{~b}\end{array}$ & * & 23 \\
\hline NK1 RRIM 600 & $\begin{array}{l}3.32 \pm 0.07 a \\
2.91 \pm 0.39 b\end{array}$ & ns & 29 \\
\hline T2 RRIM 600 & $\begin{array}{l}1.52 \pm 0.18 a \\
0.65 \pm 0.04 b\end{array}$ & * & 39 \\
\hline
\end{tabular}

ns = not significant; ${ }^{*}$ Significant at $p<0.05$ (Student's t-test); C.V. = Coefficient of variation. 
clonal variety RRIM 600 had different latex yields depending on the location. This variation might be due to the environment differences between locations, and might also vary by tapping season (Gonçalves et al., 2005b).

\section{Biochemical parameters of latex}

Studies of the physiological characteristics of latex have led numerous authors to define biochemical parameters connected with latex production. The clones selected, except for SK1, had higher dry rubber contents than RRIM 600. In this study, the RRIM 600 clones had stable TSC, Suc, Pi and RSH contents in latex (Table 3), regardless of sampling location. This is consistent with the observation that environment had no effect on the metabolism of latex regeneration (Eschbach et al., 1984). However, the biochemical parameters were directly affected by the clonal variety. For the two years of monitoring, the TSC values for all the selected clones were higher than for RRIM 600 (Table 3). However, Suc and $\mathrm{Pi}$ contents, for the most part, did not differ between the clones selected and RRIM 600, with the exception of NK1. Moreover, all the clones selected were similar to the control in their RSH content in latex.

Table 2 - Renewed bark thickness of SK1, SK3, NK1 and T2 rubber tree clones compared with RRIM 600 grown in the same farmer trail. The data were recorded from 2011-2013.

\begin{tabular}{|c|c|c|c|}
\hline Clone & Renewed bark thickness & t-test & C.V. \\
\hline & $\mathrm{mm}$ & & $\%$ \\
\hline $\begin{array}{l}\text { SK1 } \\
\text { RRIM } 600\end{array}$ & $\begin{array}{l}7.72 \pm 0.21 \\
6.66 \pm 0.28\end{array}$ & * & 6 \\
\hline $\begin{array}{l}\text { SK3 } \\
\text { RRIM } 600\end{array}$ & $\begin{array}{l}6.49 \pm 0.39 \\
6.36 \pm 0.28\end{array}$ & ns & 17 \\
\hline $\begin{array}{l}\text { NK1 } \\
\text { RRIM } 600\end{array}$ & $\begin{array}{l}6.61 \pm 0.16 \\
6.00 \pm 0.28\end{array}$ & ns & 12 \\
\hline $\begin{array}{l}\text { T2 } \\
\text { RRIM } 600\end{array}$ & $\begin{array}{l}8.91 \pm 0.19 \\
6.83 \pm 0.29\end{array}$ & * & 10 \\
\hline
\end{tabular}

Overall the clones selected were similar in their latex biochemical parameters to RRIM 600, except for the NK1 clone. The NK1 had a higher dry rubber content and better latex biochemical parameters. This clone exhibited high latex yield together with low Suc and high Pi contents. The low Suc content suggests active sucrose catabolism in the lactiferous cells. Moreover, the 2-fold increase in $\mathrm{Pi}$ content indicates active metabolism in latex regeneration, which has been correlated with rubber yield (Tang et al., 2013). However, the RSH content did not differ from RRIM 600. This is consistent with the biochemical parameters for a superhigh-yielding PR 107 clone (SY 107), which had 7-fold higher latex production than the control, while its Suc and $\mathrm{RSH}$ contents were lower than for the control. However, the TSC and Pi contents showed no difference from the control. Therefore, all these latex composition characteristics suggest that the NK1 clone should have superior latex yield.

TSC affects the viscosity of latex so that a high TSC may limit the yield by hindering latex flow, while a low TSC indicates weak latex regeneration. Sucrose is the precursor of isoprene synthesis, and a high content of sucrose indicates either a good supply to the lactiferous system or poor utilization with weak isoprene synthesis. Inorganic phosphorus $(\mathrm{Pi})$ is required for active metabolism because of its roles in phosphorylated compounds and in energy processes. Thiols protect the lutoid membranes, contribute to the redox balance, and activate the key enzymes in the laticiferous system. To obtain information about such biochemical differences in the latex between the four selected clones we used the high-yielding RRIM 600 clone (known for mediumhigh metabolism) as a paired control.

\section{Laticiferous system characteristics}

The anatomical characteristics of latex vessels for the various Hevea clones used in this study are illustrated in Figure 2. These characteristics were higher

Table 3 - Evaluation of dry rubber content (DRC) and latex biochemical parameters of SK1, SK3, NK1 and T2 rubber tree clones compared with RRIM 600 grown in the same farmer trail. The data were recorded from 2011-2013.

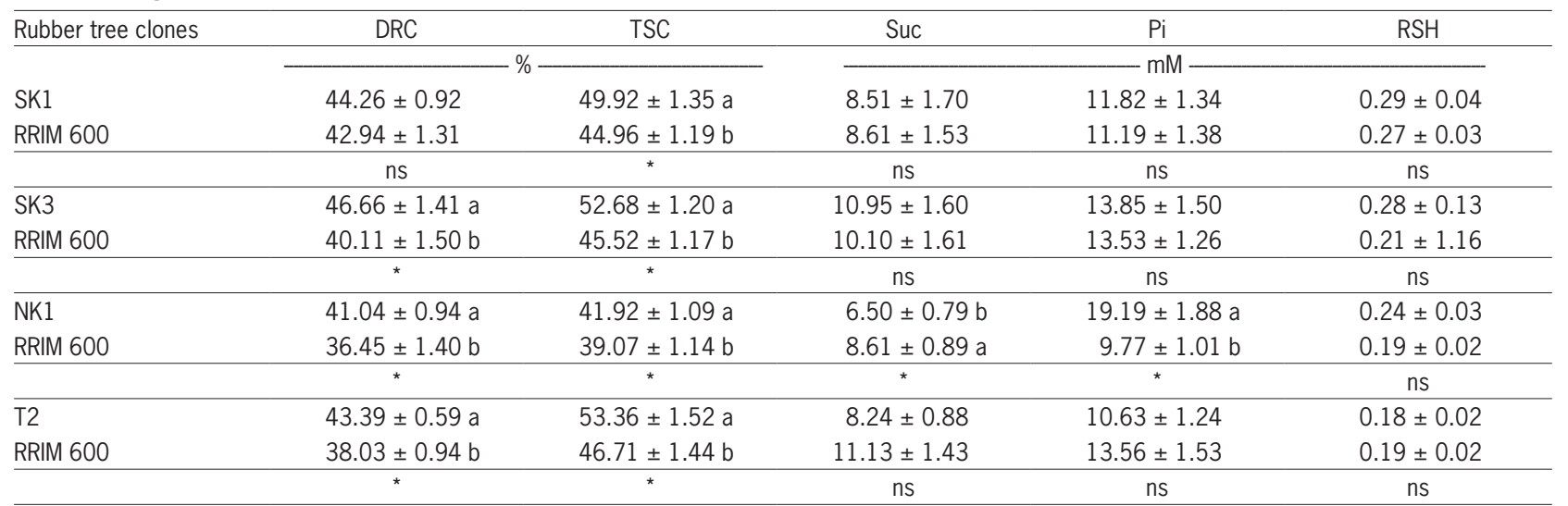

ns = not significant; ${ }^{*}$ Significant at $p<0.05$ (Student's t-test); TSC = total solid content; Suc $=$ sucrose; $\mathrm{Pi}=$ inorganic phosphorus. 
in the four selected clones than in the controls RRIM 600 and RRIT 251. The highest $41.8 \mu \mathrm{m}$ latex vessel diameter was found in NK1, followed by SK1, SK3 and T2. The vessel diameters in RRIM 600 and RRIT 251 ranged from 32.3-32.9 $\mu \mathrm{m}$ (Table 4), and a similar diameter range for RRIM 600 has been previously reported by Mesquita et al. (2006), who found $34.38 \mu \mathrm{m}$ in this productive clone and $28.62 \mu \mathrm{m}$ in an intermediately productive clone (GT 1). However, the GT 1 clone did not differ from the less productive Fx2261 clone, indicating that such an anatomical difference might only be an indicator in high productivity clones in which a smaller diameter would limit production (Mesquita et al., 2006).
The number of densities in the four selected clones were in the range 94.6-101.0 vessels $\mathrm{mm}^{-2}$, which is higher than the 84.0 vessels $\mathrm{mm}^{-2}$ in RRIM 600 or the 89.6 vessels $\mathrm{mm}^{-2}$ in RRIT 251. In contrast, Mesquita et al. (2006) reported that RRIM 600 had 126.96 laticiferous cells per $\mathrm{mm}^{2}$, which is clearly more than what we found. The age of the tree sampled might explain such differences. The density of latex vessels varies greatly between individuals and with age, as well as with clonal variety (Riches and Gooding, 1952).

For the purposes of selection, relating the anatomy of latex vessels to the latex yield might be very useful. The latex vessels are arranged in concentric cylinders among the phloem tissue. In a cross section these
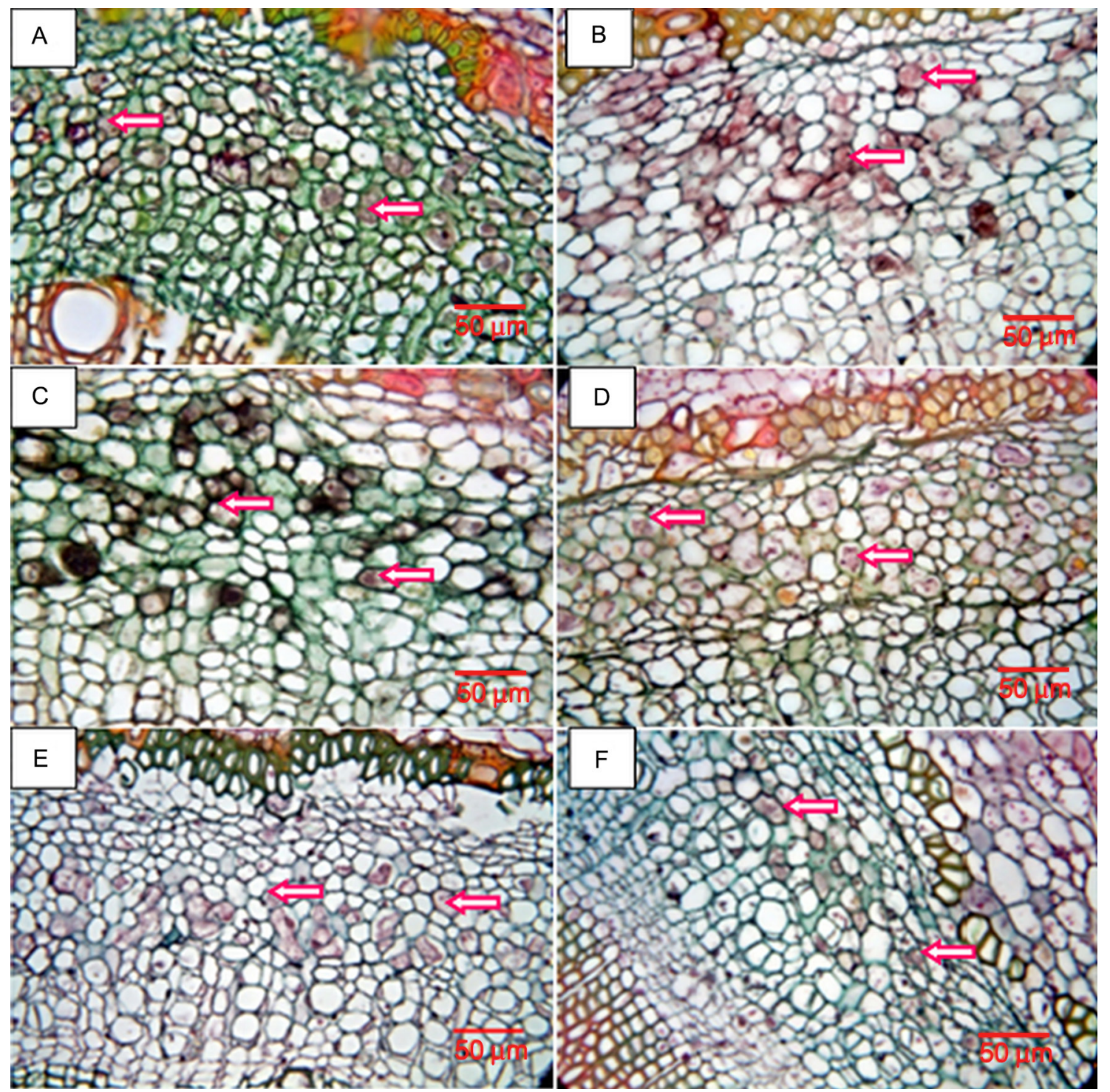

Figure 2 - Cross section of bark tissue of six Hevea brasiliensis clones A: SK1, B: SK3, C: NK1, D: T2, E: RRIT 251 and F: RRIM 600. The arrows indicate laticiferous cells. Bars $=50 \mu \mathrm{m}$. 
Table 4 - Diameter and density of latex vessels in four selected rubber tree clones compared with RRIM 600 and RRIT 251.

\begin{tabular}{lcc}
\hline Rubber tree clones & Diameter of latex vessel & Density of latex vessels \\
\hline & $\mu \mathrm{m}$ & vessels $\mathrm{mm}^{-2}$ \\
SK1 & $39.3 \mathrm{a}$ & $101.0 \mathrm{a}$ \\
SK3 & $37.5 \mathrm{ab}$ & $94.6 \mathrm{~b}$ \\
NK1 & $41.8 \mathrm{a}$ & $95.6 \mathrm{ab}$ \\
T2 & $37.5 \mathrm{ab}$ & $95.4 \mathrm{ab}$ \\
RRIM 600 & $32.3 \mathrm{~b}$ & $84.0 \mathrm{bc}$ \\
RRIT 251 & $32.9 \mathrm{~b}$ & $89.6 \mathrm{bc}$ \\
\hline F-test & $*$ & $*$ \\
\hline C.V. (\%) & 10 & 5
\end{tabular}

${ }^{*}$ Significant $p<0.05 ;$ C.V. $=$ Coefficient of variation; Means followed by the same letter do not differ(DMRT test, $p \leq 0.05)$.

cylinders appear as rings, known as latex vessel rings (Gomaz, 1982), and this reference suggests that the anatomical parameters could be used as selection criteria in clonal selection breeding. For example, the number of latex vessels accounted for $75 \%$ of the yield variation for clones in the nursery phase, but only for $40 \%$ at maturity. The number of latex vessel rings continues to be the most important single property highly related to yield (Gomaz, 1982). Additionally, the average number of lactiferous rings is the most important characteristic in the lactiferous system, and it increases with age while being inherent to the clone genotype (Webster and Paardekooper, 1989). Ho et al. (1973) reported that the number of lactiferous vessels was a determinant of the yield from adult rubber trees.

\section{Genetic similarity analysis}

In total, 21 genotypes of rubber tree had four major clusters (groups) in this analysis (Figure 3). Group 1 with 11 rubber clones included the SK1, SK3 and T2 clones. This group had two distinct subgroups with SK1, SK3, RRIM 600, and PB 310 in one subgroup, while T2 was in the other together with GT 1, BPM 24, RRIT 156, RRIT 402, RRIC 110 and AVROS 2037. The second cluster (Group 2) had only two rubber clones: PB 255 and PB 260. The NK1 clone was in the third group with six other clones: BPM 1, Tjir 1, RRIT 250, RRIT 251, PB 235, and PB 311. The last group consisted of the single clone, PR 255, indicating that this clone was strongly dissimilar from all the other rubber trees compared here, by genotype. This is suggestive of how the four selected rubber tree genotypes relate to other recommended clones, as the dendrogram is suggestive of phylogeny.

Plant breeders seek to favorably affect the phenotype through genotype, and an assessment of the genotype is important for such programs. The interest in genotype does not only cover the cultivated plant varieties, but also the related wild species and mutants that offer compatible sources for breeding.

Varghese et al. (1997) suggested the RAPD technique as an effective method to identify rubber tree

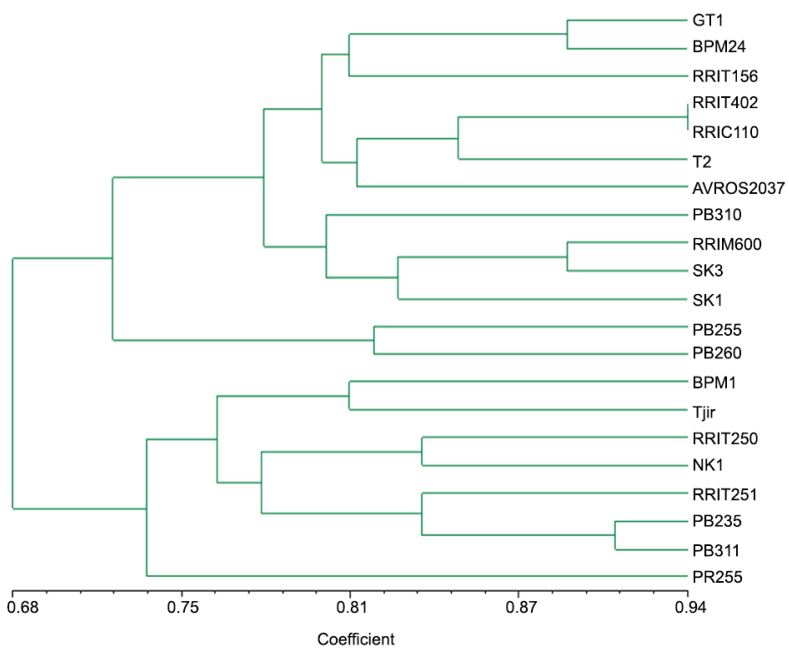

Figure 3 - UPGMA dendrogram of four selected (SK1, SK3, NK1 and T2) and seventeen recommended rubber clones based on Jaccard genetic distance matrix using eight Random Amplified Polymorphic DNA (RAPD) primers and six Simple Sequence Repeats (SSR) primers.

clones and to analyze their genetic relationships. Oktavia et al. (2011) applied 12 RAPD primers to study the genetic variability among 45 rubber clones, and to select the parent clones in rubber breeding programs. Apart from RAPD, several SSR primers have been developed for genetic analysis of $H$. brasiliensis (Saha et al., 2005). The combined use of these different marker systems provides a more reliable analysis than either one alone. The RAPD and SSR markers have been used to assess the genetic diversity in many crops, such as alfalfa (Mengoni et al., 2000), raspberry (Badjakov et al., 2006) and eggplant (Demir et al., 2010). Overall genetic similarities in the current study were in the range 0.591-0.936, which agrees with the findings in Nakkanong et al. (2008). According to the UPGMA analysis based on RAPD and SSR markers, SK3 and SK1 are closely related to the reference clone RRIM 600 , with high similarity coefficients 0.891 and 0.809 , respectively. The NK1clone is closely related to RRIT 250 with a similarity coefficient of 0.836 . The rubber clone T2 from Trang province is closely related to RRIC 110 with a similarity coefficient of 0.864 . The highest genetic similarity was found between RRIT 402 and RRIC 110, while the lowest genetic similarity, 0.591, was recorded for the three pairs Tjir 1 and PB 310; Tjir 1 and SK1; and SK1 and PB 235.

Nakkanong et al. (2008) determined the relationships between 87 early introduced and recommended clones using RAPD and SSR techniques, and found the highest similarity, 0.929, between RRIT 250 and RRIM 600. However, the genetic similarity of these clones, 0.700 , was much lower in the present study. This difference is likely due to the selection of primers, which determines which genomic regions are to be 
compared: similarities from only a partial assessment of the genome are necessarily biased, but genome sequencing, in its entirety, was not possible in the current study. An assessment of genetic similarity might be useful in selecting the parents for a rubber breeding program aimed at obtaining heterosis effects.

The dendrogram in Figure 3 provides such information visually with clear separation into four main clusters. As expected, most of the recommended genotypes fell into clusters that correspond to their pedigree data, which corroborates that the combination of both markers provided reasonable genotypic similarity scores. An assessment of genetic variability within the germplasm is of interest to practical applications in breeding, where it can rapidly identify the breeding materials. It is crucial for genetic improvement and elite gene exploitation, where high yield related genes have been identified.

This study supports using selected rubber clones in the genetic improvement of $H$. brasiliensis by selective breeding. Yield figures observed over two years indicated that the open pollinated clones selected were superior to the RRIM 600 control. The NK1 clone was outstanding in its high latex yield with good latex biochemical parameters. Also, the anatomical characteristics of the bark indicated that this clone is prime genetic material for further rubber tree improvement.

Better study data could be obtained in the case where all the selected clones were grown in shared environmental locations, and if data were collected over a longer period of time, which would also allow for an evaluation of stability of these clones. The RAPDs and the SSRs, that have been selected on the basis of high polymorphism information content, successfully discriminated between the rubber tree genotypes in this study. Genetic similarities from the combined markers fell between 0.600 and 0.936 , demonstrating that the marker combination clearly discriminated between plants with close genetic backgrounds (Mengoni et al., 2000; Rahman, 2003). The SK3 and SK1 clones were closely related to the RRIM 600, with similarity coefficients of 0.891 and 0.809 , respectively. The NK1 and T2 clones were closely related to RRIT 250 (0.836) and RRIC 110 (0.864), respectively. This suggests that DNA profiles based on a panel of selected RAPD and SSR markers could be efficiently used to assess the genetic relationships between rubber tree genotypes.

\section{Acknowledgements}

To the National Research University Project, Office of the Higher Education Commission, Prince of Songkla University, for financial support. Part of this study was also finance by a grant by the Thailand Research Fund. The authors would like to thank the Associate Professor Seppo Karrila and the Publication Clinic, Research and Development Office, Prince of Songkla University, for technical comments and manuscript correction.

\section{References}

Ahmed, N.; Mir, J.I.; Mir, R.; Rather, N.; Rashid, R.; Wani, S.H.; Shafi, W.; Mir, H.; Sheikh, M.A. 2012. SSR and RAPD analysis of genetic diversity in walnut (Juglans regia L.) genotypes from Jammu and Kashmir, India. Physiology and Molecular Biology of Plants 18: 149-160.

Badjakov, I.; Todorovska, E.; Kondakova, V.; Boicheva, R.; Atanassov, A. 2006. Assessment the genetic diversity of bulgarian rasberry germplasm collection by microsattellite and RAPD markers. Journal of Fruit and Ornamental Plant Research 14: 61-76.

Bricard, P.; Nicolas, D. 1989. Possibility of the use of the physiological parameters of latex in early selection. p. 383-403. In: D'Auzac, J.; Jacob, J.L.; Chrestin, H., eds. Physiology of rubber tree latex. CRC Press, Boca Raton, FL, USA.

Demir, K.; Bakir, M.; Sarıkamıs, G.; Acunalp, S. 2010. Genetic diversity of eggplant (Solanum melongena) germplasm from Turkey assessed by SSR and RAPD markers. Genetics and Molecular Research 9: 1568-1576.

Doyle, J.J.; Doyle, J.L. 1990. Isolation of plant DNA from fresh tissue. Focus 12: 13-15.

Eschbach, J.M.; Roussel, D.; Sype, H. van de; Jacob, J.L. 1984. Relationships between yield and clonal physiological characteristics of latex from Hevea brasiliensis. Physiologie Vegetales 22: 295-304.

Gomaz, J.B. 1982. Anatomy of Hevea and its influence on latex production. Percetakan Adabi, Kuala Lumpur: Malaysian Rubber Research and Development Board.

Gonçalves, P.S.; Cardinal, A.B.B.; Costa, R.B.; Bortoletto, N.; Gouvea, L.R.L. 2005a. Genetic variability and selection for laticiferous system characters in Hevea brasiliensis. Genetics and Molecular Biology 28: 414-422.

Gonçalves, P.S.; Moraes, M.L.T.; Bortoletto, N.; Costa, R.B.; Gonçalves, E.C.P. 2005b. Genetic variation in growth traits and yield of rubber trees (Hevea brasiliensis) growing in the Brazilian state of São Paulo. Genetics and Molecular Biology 28: 765-772.

Gonçalves, P.S.; Silva, M.A.; Aguiar, A.T.E.; Martins, M.; Junior, E.J.S.; Gouvêa, L.R.L. 2007. Performance of new Hevea clones from IAC 400 series. Scientia Agricola 64: 241-248.

Gonçalves, P.S.; Junior, E.J.S.; Martins, M.A.; Moreno, R.M.B.; Branco, R.B.F.; Gonçalves, E.C.P. 2011. Assessment of growth and yield performance of rubber tree clones of the IAC 500 series. Pesquisa Agropecuaria Brasileira 46: 1643-1649.

Ho, C.Y.; Narayanan, R.; Chen, K.T. 1973. Clonal nursery studies in Hevea. I. Nursery yields and associated structural characteristic and their variations. Journal of the Rubber Research Institute of Malaya 4: 305-316.

Jacob, J.L.; Prevot, J.C.; Roussel, D.; Lacrotte, R.; Serres, E.; D'Auzac, J.; Eschbach, J.M.; Omont, H. 1989. Yield limiting factors, latex physiological parameter, latex diagnosis, and clonal typology. p. 345-382. In: D'Auzac, J.; Jacob, J.L.; Chrestin, H., eds. Physiology of rubber tree latex. CRC Press, Boca Raton, FL, USA.

Mengoni, A.; Gori, A.; Bazzicalupo, N. 2000. Use of RAPD and microsatellite (SSR) variation to assess genetic relationships among populations of tetraploid alfalfa, Medicago sativa. Plant Breeding 119: 311-317. 
Mesquita, A.C.; Oliveira, L.E.M.; Mazzafera, P.; Delu-Filho, N. 2006. Anatomical characteristics and enzymes of the sucrose metabolism and their relationship with latex yield in the rubber tree (Hevea brasiliensis Muell. Arg.). Brazilian Journal of Plant Physiology 18: 263-268.

Nakkanong, K.; Nualsri, C.; Sdoodee, S. 2008. Analysis of genetic diversity in early introduced clones of rubber tree (Hevea brasiliensis) using RAPD and microsatellite markers. Songklanakarin Journal of Science and Technology 30: 553-560.

Oktavia, F.; Kuswanhadi, L.M. 2011. Genetic relationship of Wickham and IRRDB 1981 rubber population based on RAPD markers analysis. HAYATI Journal of Biosciences 18: 27-32.

Oktavia, F.; Mudji, L.; Nhadi, K. 2011. Selection of parent trees for Rubber (Hevea brasiliensis) breeding based on RAPD analysis. Nusantara Bioscience 3: 124-129.

Priyadarshan, P.M.; Gonçalves, P.S.; Omokhafe, K.O. 2009. Breeding Hevea rubber. p. 469-522. In: Jain, S.M.; Priyadarshan, P.M., eds. Breeding plantation tree crops: tropical species. Springer Science, New York, NY, USA.

Rahman, R.P. 2003. Microsatellite DNA and RAPD fingerprinting, identification and genetic relationships of hybrid poplar (Populus $\times$ canadensis) cultivars. Theoretical and Applied Genetics 106: 470-477.

Riches, J.P.; Gooding, E.G.B. 1952. Studies in the physiology of latex. New Phytologist 51: 1-10.

Saha, T.; Roy, C.B.; Nazeer, M.A. 2005. Microsatellite variability and its use in the characterization of cultivated clones of Hevea brasiliensis. Plant Breeding 124: 86-92.
Tang, C.; Xiao, X.; Li, H.; Fan, Y.; Yang, J.; Qi, J.; Li, H. 2013. Comparative Analysis of Latex Transcriptome Reveals Putative Molecular Mechanisms Underlying Super Productivity of Hevea brasiliensis. PLoS ONE 8: e75307.

Thanseem, I.; Joseph, A.; Thulaseedharan, A. 2005. Induction and differential expression of $\beta$-1,3-glucanase mRNAs in tolerant and susceptible Hevea clones in response to infection by Phytophthora meadii. Tree Physiology 25: 1361-1368.

Varghese, Y.A.; Knaak, C.; Sethuraj, M.R.; Ecke, W. 1997. Evaluation of random amplified polymorphic DNA (RAPD) on Hevea brasiliensis. Plant Breeding 116: 47-57.

Venkatachalam, P.; Jayasree, P.K.; Sushmakumari, S.; Jayashree, S.; Rekha, K.; Sobha, S.; Priya, P.; Kala, R.G.; Thulaseedharan, A. 2007. Current perspectives on application of biotechnology to assist the genetic improvement of rubber tree (Hevea brasiliensis Muell. Arg.): an overview. Functional Plant Science and Biotechnology 1: 1-17.

Webster, C.C.; Paardekooper, E.C. 1989. The botany of the rubber tree. p. 57-84. In: Webster, C.C.; Baulkwill, W.J., eds. Rubber. Longman, New York, NY, USA.

Zhan, Q.; Zhou, L.; Bi, N.; Wu, H.; Li, J.; Lu, J.; Lu, J.; Lin, P. 2012. A comprehensive analysis of genetic diversity and relationships of 13 sweet sorghum varieties as energy sources. Journal of Sustainable Bioenergy Systems 2: 86-91. 